\title{
Criminal Punishment in Islamic Societies: Empirical Study of Attitudes to Criminal Sentencing in Iran
}

\author{
Ghassem Ghassemi
}

Published online: 20 March 2009

(C) Springer Science + Business Media B.V. 2009

\begin{abstract}
Public opinion on criminal sentencing and aims of punishment has been surveyed mostly in Western countries. In non-Western countries, especially Islamic societies, little has been published, at least in Western journals, on these issues. In fact, no published study examining public views toward criminal sentences and the aims of punishments in Islamic societies may be located in any major database of Western literature. As a result many questions like the relationship between perceived purpose of criminal punishment and its severity and the interactions between the belief in Islam and its Shari'a (Islamic culture) and punitive attitude to criminality have remained unasked. Therefore, the meaning and motive behind the death penalty and other severe forms of punishment in Islamic countries remains unknown to scholars, whether within or outside these countries. This paper introduces, first, Shari'a sentencing laws and practices in some Islamic societies and then, by drawing on a survey administered in Iran in 2008, tries to show and explain the variations in attitudes to Shari'a criminal laws and different forms of punishment, mostly based on Shari'a, across different genders and professions (judges, lawyers, students, Tulab and police).
\end{abstract}

Keywords Attitude $\cdot$ Criminal punishment $\cdot$ Iran $\cdot$ Islamic societies $\cdot$ Shari'a

"Law", here, there, or anywhere, is a part of a distinctive manner of imagining the real.

C. Geertz, Local Knowledge

G. Ghassemi $(\bowtie)$

Max Planck Institute for Foreign and International Criminal Law, Freiburg, Germany

e-mail: ghassem.ghassemi@gmail.com 


\section{Introduction}

Public opinion on criminal sentencing and the aims of punishment have been surveyed mostly in Western countries. This is while in non-Western countries, especially Islamic societies, little has been published, at least in Western journals, on these issues. In fact, no published study examining public views toward criminal sentences and the aims of punishments in Islamic societies may be located in any major database of Western literature. As a result many questions regarding the relationship between the Islamic belief and Islamic Shari'a and punitive attitude to criminality have remained unanswered. Therefore, the level and reason of support for the death penalty and other severe forms of punishment in countries which apply Islamic law in its entirety, for instance; Iran, Saudi Arabia and Yemen and other Islamic countries, remain unknown to scholars, whether within or outside these countries.

Studying criminal punishment in Islamic countries, which have their own rationale behind punishing criminals, helps us to understand the nature of punishment as a social institution. Moreover, unraveling social and cultural conditions of penal practices in these countries reduces the level of "absurdity" and "idiosyncrasy" of some penal options in these countries. As Albrecht (2002) rightly notes: "criminal sanctions are not merely factual consequences of norm violation but themselves represent norms and are therefore not easily transplanted into another social system." (2001) (Emphasis added). Indeed, criminal punishment is not a mere reaction to law breaking behavior to restore the violated norm, but also, and sometimes even more, symbolizes and implies the people's perception of effective and legitimate "ceremonies of degradation" (Grafinkel 1956), "means of deterrence" and/or "rehabilitation". Therefore, the forms that criminal punishment may take in each society are strongly dependent on cultural values, historical collective memories and the judiciopolitical climate which depict particular modes of punishment as legitimate responses to crime, whether because of their effectiveness or perceived sacredness.

This paper first gives a description of sentencing laws and practices in some countries whose punishing power is based on Shari'a and legitimized through it. It then goes on to discuss some results of a survey on penal attitudes conducted in Iran in January, 2008.

\section{Shari' $a$ and Law Making in Islamic Countries}

In the Islamic Republic of Iran (IR) according to Article 4 of the Constitution all sorts of legislation; civil, penal, financial, economic, administrative, cultural, military, political, and other laws and regulations, must be based on Islamic criteria. However, Islamic (Shari'a) criteria provide a normative framework for legislative action and governmental practice in some other countries too.

Article 3 of the Constitution of the Republic of Yemen stipulates that the Islamic Shari' $a$ is the source of all legislation. Article (46) of the Constitution states that: "Criminal liability is personal. No crime or punishment shall be undertaken without a provision in the Shari' $a$ or the law. The accused is innocent until proven guilty by a final judicial sentence, and no law may be enacted to put a person to trial for acts committed retroactively." However, in addition to state law, Shari'a is still a source of reference in judicial decisions. The same is true in Saudi Arabia, Pakistan and Bahrain where Shari'a provides the main, or a main, legitimate base for public policy making.

However, in other Islamic societies whose political order is not rested on Islam and its injections, Shari'a still plays a significant role in public and private life and competes with or even contradicts state laws. Therefore, Islamic punishments may be exercised by 
ordinary Muslims who do not believe in state penal laws and wish for an Islamic way of justice.

This shows that in any penal reform the view of the public (elite or ordinary people) must be taken into consideration if the planned reforms are to be practiced and realized in a way that is compatible with the aims behind them. Otherwise the reforms would be born dead or at best would be translated into the dominant legal culture and become counter productive.

\section{Evolution of Punishment in Islamic Countries}

Like other countries criminal punishment has been one of the most controversial issues in Islamic societies. However, debates over penal policies and practices in the Islamic world are moving between poles which are ideologically and philosophically different from those of other countries.

The penal pendulum in the Western world has swung among different ideological poles from liberal ideology to welfarist penal strategies and again to neo-liberal ideals (Garland 1990, 2001). More clearly, as Bottoms (1995) argues changes in modern sentencing and punishment in the West may be understood by reference to four main conceptual developments: human rights/just desert, managerialism, community and populist punitiveness.

This is while in the Islamic world criminal sentencing has been oscillating between sacred/solid and secular/dynamic perceptions of crime and punishment. In other words, the debate has been revolving around Islamic or secular ways of control and punishment. Criminal punishment in the West has been justified through utilitarian and deontological philosophies or a combination of both. In contrast to Islamic justification of punishment which is based on the divine will of God, Western penal justifications depart from human intellect and argue either for the maximum welfare of society or autonomy of the free moral agent.

Therefore the normative account of punishment in Islamic societies is constructed, maintained and balanced in a quite different way than that in the West. Penal justification in Islam, due to its being beyond human reason, may not be tested and challenged by terrestrial values like individual autonomy, pubic welfare and happiness or many other values derived from them.

An Islamic state or ruler should, rhetorically, administer the will of God on earth. Crime and punishment are revealed by God in the Quran and have been practiced by the Prophet Muhammad which constitute the penal Sunna (deeds) of the prophet and are binding over the modern successors of Islamic power. An Islamic ruler is accountable only before God. He has to strive for social peace, justice and public welfare only in the normative framework of Islamic Shari'a.

Furthermore, influenced by post colonial thoughts and the thrust to Islamization from the 1970s onwards, Islamic Shari' $a$ is considered as the core of social and individual identity of Muslims which must be upheld against "the cultural invasion of the West". In fact, Islamic identity is embodied in Shari'a laws. This amounts to a defensive position in which Islamic rulers, to show their resistance to Western culture, including penal culture, sometimes invoke the most symbolic part of Shari'a. Indeed, Islamic punishment is applied not only to keep social safety and deter potential criminals from crime, but also to defend the cultural borders of Islamic society against the "corrupt culture" of the West.

However, the politicization of Islam during the last four decades has transferred the debates from secular and sacred penal order to "minimal Islamic order" and "maximal Islamic order". Muslim intellectuals throughout the Islamic World have tried to show that 
the Islamic laws, including penal laws, in their form are not a-historic, universal and immutable. It is, in their view, the message behind the laws which constitute the "Essence of Islam". Thus, legal forms and regulations are susceptible to change according to the will of the Muslim mass and the requirements of the time and place within which Islam is practiced. ${ }^{1}$

These stories may well be the same or similar in every Islamic society whose political and penal authority is based on Islamic Shari'a and is committed to the implementation of Islamic rules in society according to their constitutions.

In the following pages Islamic penal options, in law and practice, will be briefly reviewed.

\section{Islamic Crimes and Punishments}

Corporal punishments are one of the common punishments in Islamic societies whose penal policies and practices are mostly authorized and legitimized by Islamic Shari'a. Corporal punishments are imposed within three categories: Hudud, Qisas and Taazirat.

\section{Hudud Punishments}

Hudud (Plural of Hadd, meaning boundary) are crimes whose punishments are expressly determined by the holy legislator in the Quran or Sunna. These crimes are: adultery, sapphism, procuring (Qawadi), sexual slander (Qazf) (falsely accusing somebody of adultery or sodomy), drinking alcohol, rebellion and corruption on earth (Muhariba), and burglary (special kind of theft).

Whipping is the Hadd punishment for adultery, sapphism, procuring, sexual defamation and drinking alcohol. Maximum amount of Hadd lashes is 100 , some offences receive 80 lashes and the minimum amount is 75 lashes.

Rebellion and corruption on earth and burglary are punished by amputation. The perpetrator of rebellion is to be punished either by cross maiming of his/her hand and foot, crucifixion for three days, banishment or death. According to Iran's penal code the judge has the discretion to decide on the type of punishment. However, the administration of crucifixion has not been reported.

On January 6, 2008, ISNA, Iranian Students' News Agency, reported the imposition and execution of the Hadd of Muhariba on five criminals in Sistan, a south eastern province of Iran. One of the criminals was convicted of blocking the highway with force and resisting the police officers through which an officer was injured; two others were convicted of armed robbery, hostage taking, and disturbing public order, and two others were convicted of armed theft and disturbing public safety. They were sentenced to cross-amputation of the right hand and left foot (ISNA 2008).

The amputation of four fingers of the right hand is the Hadd punishment for burglary. This punishment is imposed to even less serious crimes in Saudi Arabia were the right hand of an Egyptian man was amputated in Mecca after he was found guilty of pick-pocketing inside the Grand Mosque in 2007 (Reuters). In another case in 2003, a Bangladeshi citizen convicted of committing theft inside the Holy Mosque of Mecca was punished by hand amputation (SPA). In northern Nigeria a man convicted under Islamic law of steeling cows

\footnotetext{
${ }^{1}$ Abdolkarim Soroush, Mohammed Mujtahid Shabestari, Nasr Hamid Abu Zayd, Mohammed Arkoun, have published various books and articles in Farsi and Arabic supporting these ideas.
} 
had his right hand amputated in 2000 (AP 2000) and more recently another man convicted for the theft of a cell phone and other items was sentenced to the same punishment (South African Press Association 2006). In recent years in Iran (2007-2008), the conviction and implementation of this punishment was reported in Mashad (four implementations), Kermanshah (implemented more than once), Tehran (three convictions) and Karaj (three convictions).

In other Islamic countries like Pakistan since the 1979 Islamization of penal law (Usmani 2006) and Aceh (as of 2006), the northernmost province of the Indonesian island of Sumatra, a thief may be sentenced to amputation when the legal (Shari'a) requirements are present.

Other types of Hadd crimes such as sodomy, rape and incest, are punished by the death penalty. Several death sentences have been inflicted on rape offenders during the last years. Unfortunately, there is no statistics on the administration of punishment. However, newspapers reported the execution of seven offenders in Mashad, three in Shiraz and three in Zahidan in 2007; all were convicted of rape. In Mashad and Shiraz the convicts were executed publicly, in the main square of the city where the crime happened. The last three offenders were prosecuted, tried and executed within less than three months (ISNA 2007). In most of these cases the procedural rules were ignored and the defendant's rights like access to a lawyer, public trial, and the rights of judicial revision were violated (ISNA 2007).

\section{Retaliatory Death Penalty (Qisas Punishment)}

According to the law of Qisas (retaliation) prescribed in Shari'a, a murderer may be executed (retaliated) by the heirs of the victim if they wish so. Qisas is another type of punishment which is divinely stipulated by God in the Quran. The Quran states that "O you who believe! Retaliation (Qisas) is prescribed for you in case of murder: the free for the free, the slave for the slave, and the female for the female." It continues "and in Qisas (law of retaliation) there is a life for you" (Quran). However in the same Surah (chapter), the Quran encourages Muslims to forgive their Muslim brothers who commit murder and to take the blood money (Diya) instead.

Qisas is punishment for murder and battery. Therefore, it may be enforced in two types: life Qisas and limb Qisas. If the intentional injurious act of the criminal causes the death of the victim, the heirs of the victim may take revenge and ask the judge for Qisas (death penalty). They may also commute the revengeful reaction and ask for Diya. When the intentional injurious act does not cause the death of the victim, but rather the loss of a limb or its proper function, the victim, herself/himself, may take revenge or ask for Diya.

Diya is blood money which is given to the injured victim or heirs of the murdered victim. The amount of Diya received for a murdered person and injury of different parts of body is determined in Fiqh books; the Islamic jurisprudence compiled in books of different Islamic jurists. The Diya of life in Iran is determined according to the inflation rate and the price of some special goods by the central bank of Iran every year.

Such a personal revenge, which to some extent has been bureaucratized since its application needs the approval of the head of the judiciary, gives a pleasure of being allowed to vent personal power freely upon one who is powerless (the criminal). It gives a kind of satisfaction to the victimized party. This satisfaction will be greater the lower the victimized party stands in the social order. It can easily appear to him as a most favorable result, indeed as a foretaste of higher rank (Nietzsche 1967). In revenging against the offender the victim participates in a right of masters: finally s/he is able to experience the enjoyment of being allowed to despise someone who has come beneath her/him. S/he has the right to decide over the death or life of a person. S/he can ask for a big amount of 
money, as Diya, which can give the victimized party a joy of exercising power. This is especially true when the offender is a poor person.

\section{Death Penalty}

The death penalty is not, however, limited to the Qisas or other divined forms of capital punishment. In addition to Hudud and Qisas (and its alternative Diya), Taazirat (plural form of Taazir, meaning chastisement) constitute the third form of punishments that are not determined in the Quran and Sunna. In classical Shari'a these punishments are left to the Hakim's (Islamic judge) discretion. He may determine the quality and quantity of the punishment for emerging forms of crimes or for Islamic forbidden behaviors whose punishments are not prescribed in holy sources. The only limit for discretionary Taazir punishment is that it may not exceed the Hadd punishment in quantity. This limitation has been interpreted to be viable only in whipping. However, in modern times, in some Islamic countries which apply Shari'a, Taazirat punishments have been codified.

Through codifying punishments the discretionary power of Hakim has been transferred to the Islamic legislator (Majlis). Majlis of the Islamic Republic of Iran introduced the death penalty as Taazir of some crimes (especially drug offences). Like Iran, most Islamic countries retain the death penalty as one of the penal options in their penal codes for different types of crimes. During 2007, at least 1252 people were executed in 24 countries of which 13 countries have a majority Muslim population. More than half of the executions (688) happened in these countries. The Islamic Republic of Iran (317), the Kingdom of Saudi Arabia (143) and the Islamic Republic of Pakistan (135) respectively were the three state that executed their criminal citizens most often in the Islamic world. ${ }^{2}$ Worldwide China holds the first place before Iran in executing its citizens legally, and the USA holds the fourth place. Some Islamic countries have amongst the highest executioners per capita in the world. ${ }^{3}$

\section{Taazir Punishments}

Emerging and modern forms of crimes, whose punishments are not determined in original Islamic texts, are sanctified by Taazir punishments. Most of the punishments in Islamic penal law are of Taazir nature. Imprisonment, whipping, fines, and the death penalty are the most common types of Taazir. However, in Iran's penal code punishments and penal measures such as confiscation, forfeiture, deprivation of social and civil rights, probation and parole are applicable as Taazir of crimes whose punishments are not mentioned in Shari' $a$ and for emerging types of crimes.

However, in practice imprisonment and whipping are the most common forms of punishment in Iran. This is due to the fact that most of the offenders are poor and the fine sentences lead to default imprisonment because quite often the convicted person fails to pay the fine. Therefore, indeed, judges have to decide between prison and whipping. According to the Directive on "implementation of financial convictions", Article 1: "if the convicted

\footnotetext{
${ }^{2}$ Other Islamic countries which administered the death penalty in 2007 are: Iraq, Yemen, Afghanistan, Libya, Syria, Sudan, Somalia, Kuwait, Indonesia, and Egypt.

${ }^{3}$ According to an Amnesty International report in 2006 Kuwait executed 10 people, an average of 1.8 per million.
} 
fails to pay the fine and argues that $\mathrm{s} /$ he is unable to pay it and no solid evidence contradicts her/his argument, each 100,000 Rials (about 8 Euro) should be replaced with one day imprisonment." 4

The number of prisoners has been increasing in recent years, while the capacity of prisons has not grown correspondingly, which has led to poor conditions of prisons in Iran. In February 2003 the number of prisoners exceeded about 59\% more than the nominal capacity of prisons in Iran. This phenomenon was observed most in Hamedan, Qazwin, Qom, Khurasan, Sistan and Khuzestan. Compared to 1988, the overall input of prisons has increased three times by 2003 to 622,058 . The portion of prisoners of drug-related offences also increased four times in contrast to 1988 to 234,214 of the total number of prisoners $(622,058)$ in 2003 (Miri Ashtiyani 2006). According to the Human Development Report of $2007 / 2008$ the prison population in Iran is 147,926 , that is, 214 prisoners per 100,000 (Human Development Report 2007/2008, 323). The number of population in custody per 100,000 becomes 490 when the number of detainees under temporary arrest (estimate of $210,000)$ is calculated as well. ${ }^{5}$

The overpopulated prisons have made judicial authorities think of strategies of deprisonization and early release of prisoners. As the chief of the prison organization reported it in 2006 (ILNA), the prison population, with 140,000 inmates, has grown more than ten times in contrast to 1980 when the prison population was $13,000 .^{6}$ In another interview the chief of the prison organization insisted that "the 'prisonization' of criminal law is a European and Christian phenomenon and imprisonment is not a genuine Islamic punishment." He also admitted that in Abadan, a city located in south Iran, a prison with the capacity for 70 inmates hosted about 500 inmates (ISNA 2006).

As a result of the ever-increasing number of prisoners a draft law has been prepared that introduces alternative penal sanctions which may replace both prison and whipping. Although it was handed in to the Majlis about three years ago, on August 7th, 2005, this draft has not been passed by the Majlis yet. Therefore, the chief of the judiciary asked the judges to avoid sentencing criminals to imprisonment as much as possible through administrative circulars. This is because alternative penal options have not been introduced to the criminal courts yet. At the present, whipping and pardon are common methods for managing overpopulated prisons. Early release in the form of parole and probation are two other forms of managing prison populations. However due to the institutional shortcomings like the lack of an institution which may be held responsible for supervising those on probation and the absence of probation officers in the administration of criminal sentencing, these alternatives are either not used or are used in an inconsistent and unprincipled (random) way. The semi-formal method of conflict settlement in trivial criminal matters is another strategy that the judiciary has invented to manage the caseload of the courts and overpopulated prisons. However, the conflict settlement councils principally do not provide informal processes of settlement and are the same as formal courts judging with the same laws and rules, but with legally less educated and less paid personnel. In addition, most of the cases dealt with in conflict settlement councils enter the courts and formal processes sooner or later.

To examine the attitude of the people, for, upon and by whom these penal measures are exerted, toward criminal punishment and to investigate the probable variations in some social groups, a survey was done in January, 2008.

\footnotetext{
${ }^{4}$ Passed by the Judiciary in 1999 .

${ }^{5} \mathrm{http}$ //www.unodc.org/pdf/iran/drug_crime_situation/rule_of_law/CrimeandJusticeLaws.pdf

6 Iran's population was about 49,445,010 in 1977 and 70,472,846 in 2005.
} 


\section{Hypotheses of the Survey}

Surveys of punitivity in Western countries have shown that women are, generally, less punitive than men (Kury et al. 2002). One of the hypotheses (Hypothesis 1) of this survey was that the female respondents are less punitive than their male counterparts. Women were assumed to support harsh punishments and death penalty less than men. Another assumption (Hypothesis 2) which was tested in the survey was that women are less supportive of Shari'a penal laws than men. They were supposed to favor the separation between Shari'a and penal legislation more than men. This assumption is rested on the fact that the Shari'a criminal laws to some extent discriminates against women and favor men. The survey also assumed that students support the death penalty, corporal punishment and other harsh punishment of homosexuality less than other groups of respondents (Hypothesis 3 ). It was also assumed that the Tullab (students of religious seminaries) support such punishments more than other groups (Hypothesis 4). This assumption is based on the fact that corporal punishments and death penalty for some specific crimes are perceived to be authorized by Shari' $a$. Lawyers, judges and police officers, as mentioned above, were other groups of respondents who, unlike the students and Tullab, have practical experiences and are generally older than them. However, being separate and independent from the judicial power and direct state control, it is assumed that lawyers are less supportive of the harsh punishments and solid and expansive penal control (Hypothesis 5). This assumption is held reversely for judges and police officers who deal with cases on an every day basis which should be controlled and punished according to existing laws. The final assumption (Hypothesis 6) that is tested in this paper is that the imprisonment, considerably, has lost its legitimacy among the respondents and hence whipping has acquired more legitimacy. At the end through multivariate regression analysis the effects of gender, age and profession on variances in some items have been evaluated.

\section{Sampling and Administration of the Questionnaire}

The aim of the survey was to study the attitudes of elites, those who are most influential in the formation of penal policy and criminal punishment practices. Therefore, potentially influencing groups in present penal policies and practices, including judges, members of political parties, and presumably, their future successors (law students, seminary students and students of the police academy), were sampled. However, students of other disciplines were also sampled. These are students of social sciences, other than law, mathematics and natural sciences.

To capture the attitudes of various social and ethnic groups and religious minorities in Iran, four cities, each of which holding a specific character, were selected. Tehran is the capital city of Iran which hosts the main political and administrative organizations and authorities of the Islamic Republic (IR). It is, indeed, the administrative, academic, commercial, industrial, and medical center of Iran. Therefore, not surprisingly, each year a great number of people from different parts of Iran immigrate to this city for different reasons, though particularly to study and work. Qom, perceived as "holy city", is the center of Shiite school of thought. About 50,000 Talabeh; religious seminary students, are studying in this city. Most prominent Ulama; Islamic jurists, are teaching and presiding over seminaries in this city. Ulama, especially those known as the "sources of imitation", enjoy considerable influence on governmental institutions such as Majlis, the judiciary and the government in Tehran. 
Sanandaj is the main city of the Kurdistan province in western Iran. Most of the inhabitants of this province are Kurds and are Sunnite Muslim. Ahwaz, another target city of the survey, is located in southern Iran and is the main city of the Khuzestan province. Most of the inhabitants of this city are Arabs.

The questionnaire was administered for each sample group differently. To administer the questionnaire among students and Tulab, it was distributed at the end of each class and they filled it in with the presence of the researcher. Only in Ahwaz the questionnaire was administered in student dormitory. The questionnaire was also distributed among judges in courtrooms and prosecutorial offices in Tehran, Qom, Ahwaz and Sanandaj. Most of the judges, especially in Tehran, responded to the questions in their home and returned it back to their office where they gave it back to me. Some of them filled it in on the same day and returned it back. Police officers and lawyers filled out the questionnaire in their workplace. Due to the fact that the administration method differs from one sample group to other, the response rate may not be calculated in a meaningful way. The present data, as described above, come from a convenience sample. Thus the results represent attitudes of those who participated in the survey.

The respondents were provided with indicative statements about different aspects of crime and punishment. They were asked to specify the degree of their agreement or disagreement with given statements by marking one of the boxes of a six-point scale; numerated from one to six, in that, one meant totally disagree and six meant totally agree. In the same order 5 meant agree and 2 meant disagree, 4 and 3 meant respectively to some extent agree and to some extent disagree.

\section{Students and Tulab}

After the pre-test the final version of the questionnaire was distributed among students of different disciplines and universities across Tehran, Ahwaz, Qom, and Sanandaj.

As mentioned above, Qom is conceived to be the modern center of the Shiite school where many clerics are teaching and studying Islamic jurisprudence and philosophy. Therefore, the questionnaires were distributed among the Tulab, plural of Talabeh, of this city.

It is notable that Clerics in Iran may be divided into three distinct groups. Some are engaged with political debates and aligned with different political groups (reformists or conservatives). The spiritual leader of the IR and other clerics, who run mere political institutions or serve double functions in politico-religious institutions, whether through election campaigns or appointment, are prominent examples of these clerics. Another group is politically indifferent and concerned more with their lessons and study in Islamic Shari'a, philosophy and the Quran. These clerics however are very few and are less known to the people. The third group delivers religious services to ordinary people. Clerics known as "sources of imitation" are the most prominent popular clerics who are selected by "The Instructor Society of Qom Seminary of Science". But most of the clerics of the latter group are simple narrators of religious texts and creeds produced by leading clerics.

Three groups of political, scholar, and popular clerics are the most obvious fragmentations in Iran's clerical body. Within each of these groups, other fragmentations and alignments may exist who view the relationships between Islam, the state and society in their own distinct ways.

It was important to distribute the questionnaires among the different groups of Tulab, mentioned above. To this end they were distributed in different seminaries with different interests. The questionnaire was also distributed in a female seminary in Qom. 
Table 1 Sex distribution of respondents according to the profession

\begin{tabular}{|c|c|c|c|c|c|c|}
\hline \multirow{2}{*}{$\begin{array}{l}\text { Profession } \\
\text { Gender }\end{array}$} & \multicolumn{2}{|c|}{ Female } & \multicolumn{2}{|c|}{ Male } & \multicolumn{2}{|c|}{ Total } \\
\hline & $\mathrm{N}$ & $\%$ & $\mathrm{~N}$ & $\%$ & $\mathrm{~N}$ & $\%$ \\
\hline Academic & 31 & $11 \%$ & 53 & $12 \%$ & 84 & $11 \%$ \\
\hline Student & 181 & $62 \%$ & 118 & $26 \%$ & 299 & $40 \%$ \\
\hline Lawyer & 6 & $2 \%$ & 12 & $3 \%$ & 18 & $2 \%$ \\
\hline Judge & 22 & $8 \%$ & 153 & $34 \%$ & 175 & $24 \%$ \\
\hline Police & 3 & $1 \%$ & 33 & $7 \%$ & 36 & $5 \%$ \\
\hline Tulab & 29 & $10 \%$ & 44 & $10 \%$ & 73 & $10 \%$ \\
\hline Other & 21 & $7 \%$ & 39 & $9 \%$ & 60 & $8 \%$ \\
\hline Total & 293 & $100 \%$ & 452 & $100 \%$ & 745 & $100 \%$ \\
\hline
\end{tabular}

\section{Justice Officials}

The questionnaire was distributed among different judicial jurisdictions of different types and levels, including prosecutorial judges and trial judges of general competence, especial competence and juvenile jurisdictions. The questionnaire was given to general prosecutors and high prosecutors and to judges of lower, appellate and high courts, the latter one exists only in Tehran. It is also noteworthy that the respondent judges were composed of both civil and penal judges.

However, within the 146 respondents who have been identified as judges, the majority are lower judges and prosecutors rather than higher judicial staff. Unlike Tehran, where among numerous judicial jurisdictions some jurisdictions had to be selected, in other cities like Qom, Sanandaj, Ahwaz, the questionnaires were distributed among all judges and prosecutors of the city. It is notable that some of the judges, especially those who serve as higher judges, refused to answer the questionnaires and most of the questionnaires given to these judges were returned blank.

To administer the questionnaire among police officers one of the central police stations of Tehran was selected.

\section{Socio-demographic Composition of Respondents}

Total number of respondents is 850 who are composed of the following groups:

Gender

In universities most of the students are women. As a result, as shown in Table 1, within the universities $26 \%$ of respondents are male, whereas $62 \%$ are female. This is different to the

Table 2 Sex and age composition of respondents

\begin{tabular}{|c|c|c|c|c|c|c|}
\hline \multirow{2}{*}{$\begin{array}{l}\text { Gender } \\
\text { Age }\end{array}$} & \multicolumn{2}{|c|}{ Female } & \multicolumn{2}{|c|}{ Male } & \multicolumn{2}{|c|}{ Total } \\
\hline & $\mathrm{N}$ & $\%$ & $\mathrm{~N}$ & $\%$ & $\mathrm{~N}$ & $\%$ \\
\hline$<25$ & 219 & $68 \%$ & 139 & $29 \%$ & 358 & $45 \%$ \\
\hline $26-35$ & 84 & $26 \%$ & 204 & $43 \%$ & 288 & $36 \%$ \\
\hline $36-45$ & 12 & $4 \%$ & 88 & $19 \%$ & 100 & $13 \%$ \\
\hline$>46$ & 6 & $2 \%$ & 42 & $9 \%$ & 48 & $6 \%$ \\
\hline Total & 321 & 100 & 473 & 100 & 794 & $100 \%$ \\
\hline
\end{tabular}


Table 3 Relationship between gender and attitudes to death penalty

\begin{tabular}{|c|c|c|c|c|c|c|}
\hline & \multicolumn{2}{|c|}{ Female } & \multicolumn{2}{|c|}{ Male } & \multicolumn{2}{|c|}{ Total } \\
\hline & $\mathrm{N}$ & $\%$ & $\mathrm{~N}$ & $\%$ & $\mathrm{~N}$ & $\%$ \\
\hline Totally disagree & 20 & 6 & 24 & 5 & 44 & 6 \\
\hline Disagree & 15 & 5 & 10 & 2 & 25 & 3 \\
\hline To some extent disagree & 10 & 3 & 10 & 2 & 20 & 3 \\
\hline To some extent agree & 24 & 8 & 33 & 7 & 57 & 7 \\
\hline Agree & 46 & 14 & 61 & 13 & 107 & 13 \\
\hline Totally agree & 207 & 64 & 340 & 71 & 547 & 68 \\
\hline Total & 322 & 100 & 478 & 100 & 800 & 100 \\
\hline
\end{tabular}

overall number of respondents to the questionnaire where the total number of female respondents constitutes $39 \%$ and male respondents constitute $61 \%$, (missing $=33$ ).

Age

Respondents are categorized in four age groups: Under 25, from 25 to 35, from 35 to 45 and over 45 . Table 2 shows that $45 \%$ are under 25 . People who are between 25 and 35 constitute $36 \%$ of respondents. $13 \%$ are more than 35 and under 45 . And $6 \%$ are more than 45 years old. $6.6 \%$ did not mention their age, $(\mathrm{N}=56)$ (Table 3$)$.

\section{Profession}

Within the people who mentioned their profession, $12 \%$ are academics, including those who teach in universities and researchers, $2 \%$ are lawyers, $5 \%$ police officers, $10 \%$ are Tulab (the students of religious seminaries, plural of Talabe), 23\% are judges including prosecutors and trial judges, $40 \%$ of the respondents are students and $8 \%$ have other professions, including teacher and journalist, (missing=83). Respondents in the latter group are, in fact, members of political parties as well as woman and child NGOs which, due to the weak cooperation of some political parities and the small number of returned questionnaires from NGOs, the data may not be analyzed based on these two occupations. ${ }^{7}$

\section{Place of Residence}

Respondents fall within nine groups according to their living places; $37 \%$ of respondents are living in Tehran. Western Iran including: Ardebil, Kermanshah, Hamedan, Azerbaijan Sharghi, except for cities located in Kurdistan province, constitutes $16 \%$ of respondents; $15 \%$ of respondents are living in Qom. The geographical distribution of other respondents is as follows: East including Sabzevar, Mashhad, Semnan, Sistan 2\%, South, except for Ahwaz, which constitutes a separate category, 3\%, Kurdistan 14\%, Northern Iran 4\%, Central Iran 5\%, and finally Ahwaz 5\%.

\footnotetext{
${ }^{7}$ Four political parties were sampled for the survey. Two of them are considered as conservative (Motalefeh and $J A M$ ) and two others are considered as reformist (Mosharekat and Hambastegi).
} 


\section{Findings of the Survey}

The survey shows that the respondents have rather homogenous views to different aspects of criminal punishment in Iran. This is despite the fact that the respondents live in different cities, graduated from or are studying in different majors and universities, and belong to different age groups. However, respondents may not be treated as a representative sample of the whole of Iran. They are educated people, whether in universities or religious seminaries. At the same time they, as elites, have significant influence on the opinion of lay people and, due to weak institutionalized and less bureaucratized processes of policy making, have an influential role in the formation of public policies.

Although the sample was not selected by random design, tests of the significance were used to draw attention to the important effects.

\section{Preferred Punishment for Specific Crimes Across Genders and Professions}

\section{Gender and Preferred Punishment for Murder, Theft, Improper Hijab, and Attitudes to Impunity of Honor Killing}

Recently there have been several critiques against some penal regulations such as the impunity of honor killing perpetrated by a husband ${ }^{8}$ and penal control of women's dress and their Hijab. Improper Hijab (coverage of the body) is one of the crimes sanctioned by Taazir; imprisonment from 10 days to two months or a fine according to the Islamic Penal Code (Article 638 IPC). The opinion of the respondents on these forms of penal regulations were surveyed. Qisas and amputation of the thief's finger were two other exciting penal regulations about which respondents' attitudes were studied.

The survey shows that women are less supportive of Qisas for murder, amputation of thieves' fingers and punishing women who do not have proper Hijab. They oppose the impunity of honor killer considerably more than men.

However, both men and women considerably endorse Qisas as proper punishment for murder ( $74 \%$ of female and $81 \%$ of male respondents, $\mathrm{N}=806)$. Only $10 \%$ of female and $8 \%$ of male respondents (totally) disagree with this form of punishment. The difference between men and women is not statically significant in this item.

As regards the amputation of fingers for the crime of theft, women show stronger disagreement $(36 \%)$ than men $(28 \%)$. This difference is also observable in the degree of support of this punishment, in that more than half of the male respondents (totally) agree with it, while only $37 \%$ of the female (totally) agree with this penal form $(\mathrm{N}=84)$. This difference is statistically significant $\left(\chi^{2}=28,021, p=000\right)$.

Punishing women who do not care about their Hijab (garment of the body and hair) is opposed by most of the respondents ( $51 \%$ of female and $37 \%$ of male respondents, $N=806$ ). Only $27 \%$ of women and $32 \%$ of men indicate agreement with penal control of women dressing. The difference between men and women is significant $\left(\chi^{2}=23,509, \mathrm{P}=, 000\right)$.

As stated above, according to the current Islamic Penal Code a man who finds his wife committing Zina (adultery) with another man may kill both (adulteress and adulterer) if he knows that his wife is willingly committing it. The survey shows a striking contrast of opinion between male and female respondents on this kind of impunity. While $50 \%$ of women disagree

\footnotetext{
${ }^{8}$ Article 630 of IPC “A man who finds his wife committing Zina (adultery) with another man may kill both (adulteress and adulterer) if he knows that his wife is willingly committing it. If the woman is forced he may only kill the man. In the case of battery the law is the same as killing."
} 
Fig. 1 Preferred Punishment for Murder, Theft, Improper Hijab, and Attitudes to Impunity of Honor killing

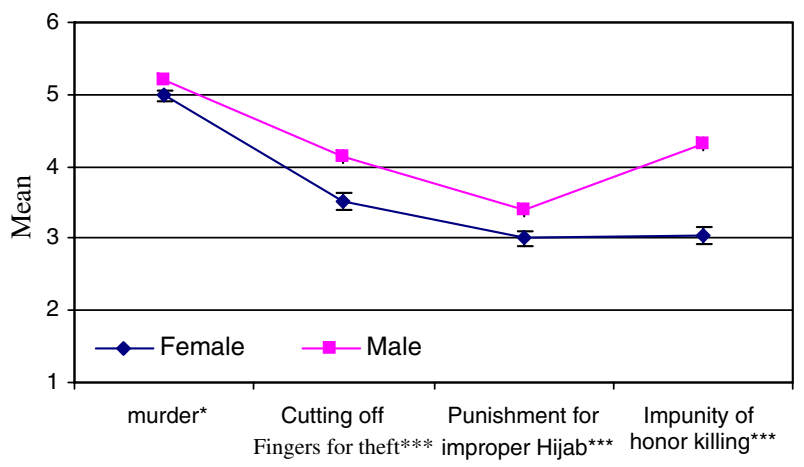

with this form of penal excuse, men show less opposition and only $24 \%$ of them indicate disagreement. Meantime, $52 \%$ of men endorse this impunity and only $33 \%$ of women hold the same opinion on it $(\mathrm{N}=802)$. Figure 1 shows the mean score of male and female respondents across all above items.

Profession and Preferred Punishment for Murder, Theft, Improper Hijab, and Attitudes to Impunity of Honor Killing

As Fig. 2 indicates, lawyers' opinions on four items, asking about specific forms of punishment for murder and theft, penal control of improper Hijab and impunity of honor killing, strikingly stand in contrast to the police officers' opinions. Except for penal control of improper Hijab, in other cases judges hold relatively similar views to police officers. Students, Tulab and other professions have almost similar scores on different items.

Attitudes to Death Penalty

\section{Gender and Death Penalty}

As Table 4 shows, $11 \%$ of female and $6 \%$ of male respondents (totally) disagree with the statement that the death penalty is necessary for some criminals. This means that only $9 \%$ of the respondents disagree with the necessity of the death penalty, while most of them $(81 \%)$ totally agree or agree with it. However, women $(78 \%)$ show less support for the

Fig. 2 Preferred Punishment for Murder, Theft, Improper Hijab, and Attitudes to Impunity of Honor killing

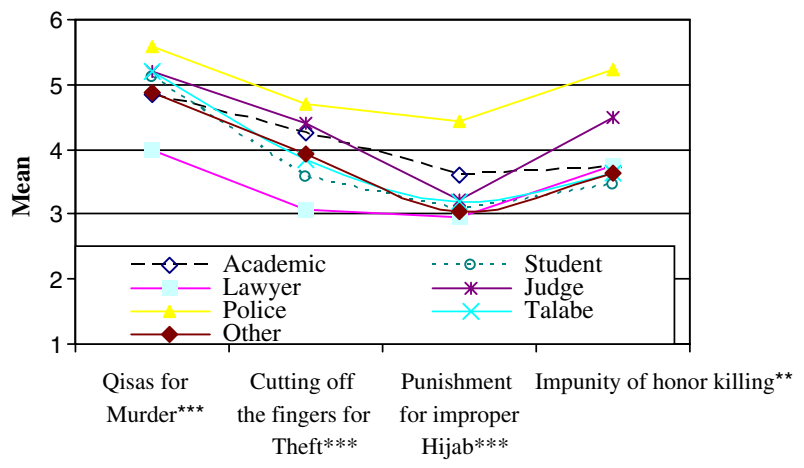


Table 4 Relationship between profession and the attitude to death penalty

\begin{tabular}{|c|c|c|c|c|c|c|c|c|c|c|c|c|c|c|c|c|}
\hline & \multicolumn{2}{|c|}{ Academia } & \multicolumn{2}{|c|}{ Student } & \multicolumn{2}{|c|}{ Lawyer } & \multicolumn{2}{|c|}{ Judge } & \multicolumn{2}{|c|}{ Police } & \multicolumn{2}{|c|}{ Tulab } & \multicolumn{2}{|c|}{ Other } & \multicolumn{2}{|c|}{ Total } \\
\hline & $\mathrm{N}$ & $\%$ & $\mathrm{~N}$ & $\%$ & $\mathrm{~N}$ & $\%$ & $\mathrm{~N}$ & $\%$ & $\mathrm{~N}$ & $\%$ & $\mathrm{~N}$ & $\%$ & $\mathrm{~N}$ & $\%$ & $\mathrm{~N}$ & $\%$ \\
\hline Totally disagree & 9 & 11 & 20 & 3 & 4 & 22 & 4 & 2 & 1 & 3 & 2 & 3 & 2 & 3 & 42 & 6 \\
\hline Disagree & 5 & 6 & 12 & 4 & 0 & 0 & 4 & 2 & 0 & 0 & 1 & 1 & 2 & 3 & 24 & 3 \\
\hline $\begin{array}{l}\text { To some extent } \\
\text { disagree }\end{array}$ & 2 & 2 & 10 & 3 & 0 & 0 & 0 & 0 & 0 & 0 & 3 & 4 & 2 & 3 & 17 & 2 \\
\hline To some extent agree & 7 & 9 & 25 & 8 & 1 & 6 & 10 & 6 & 3 & 8 & 6 & 8 & 3 & 5 & 55 & 7 \\
\hline Agree & 9 & 11 & 33 & 11 & 5 & 28 & 25 & 14 & 3 & 8 & 11 & 15 & 13 & 22 & 99 & 13 \\
\hline Totally agree & 50 & 61 & 209 & 68 & 8 & 44 & 131 & 75 & 29 & 81 & 49 & 68 & 37 & 63 & 513 & 68 \\
\hline Total & 82 & 100 & 309 & 100 & 18 & 100 & 174 & 100 & 36 & 100 & 72 & 100 & 59 & 100 & 750 & 100 \\
\hline
\end{tabular}

necessity of death penalty than men $(84 \%)$. Nonetheless, these differences are not statistically significant.

The variation of opinion on the necessity of the death penalty, though statistically not significant, is also observable in different age groups of respondents. Those who are between 35 and 45 years old show the least support (78\%) and the most disagreement $(13 \%)$ to the death penalty. The next age group which supports the death penalty less than others is under 25 year olds (79\% supporting and $8 \%$ disagreement). $84 \%$ of those who are between $25-35$ years old and $87 \%$ of those who are more than 45 years old (totally) agree with the necessity of the death penalty. This is while $8 \%$ and $11 \%$ of them respectively disagree with the necessity of this penal option for some criminals.

The mean score of the male and female respondents is shown in Fig. 2. As indicated in the figure, women have significantly lower scores than men in supporting the death penalty as a necessary punishment for some criminals.

\section{Profession and Attitudes to Death Penalty}

As shown in Table 5, different professional groups view the necessity of the death penalty differently. Lawyers support the death penalty less than other groups. However, $72 \%$ of them totally agree or agree with the necessity of the death penalty for some criminals while $22 \%$ of them express disagreement with it. Academics are the second group which oppose the death penalty the most $(17 \%)$, in comparison to other groups. However, $72 \%$ of them support this penal option for some criminals. Judges and police officers are the most

Table 5 Prison is in fact academy of crime

\begin{tabular}{|c|c|c|c|c|c|c|c|}
\hline Profession & $\begin{array}{l}\text { Totally } \\
\text { disagree }\end{array}$ & Disagree & $\begin{array}{l}\text { to some extent } \\
\text { disagree }\end{array}$ & $\begin{array}{l}\text { to some extent } \\
\text { agree }\end{array}$ & Agree & $\begin{array}{l}\text { Totally } \\
\text { agree }\end{array}$ & Total \\
\hline Academic & $15 \%$ & $5 \%$ & $16 \%$ & $13 \%$ & $24 \%$ & $28 \%$ & $100 \%$ \\
\hline Student & $7 \%$ & $7 \%$ & $9 \%$ & $18 \%$ & $27 \%$ & $33 \%$ & $100 \%$ \\
\hline Lawyer & $12 \%$ & $6 \%$ & $12 \%$ & $18 \%$ & $29 \%$ & $24 \%$ & $100 \%$ \\
\hline Judge & $12 \%$ & $10 \%$ & $12 \%$ & $26 \%$ & $22 \%$ & $18 \%$ & $100 \%$ \\
\hline Police & $8 \%$ & $17 \%$ & $3 \%$ & $19 \%$ & $14 \%$ & $39 \%$ & $100 \%$ \\
\hline Tulab & $4 \%$ & $9 \%$ & $7 \%$ & $16 \%$ & $38 \%$ & $27 \%$ & $100 \%$ \\
\hline Other & $10 \%$ & $3 \%$ & $9 \%$ & $15 \%$ & $31 \%$ & $32 \%$ & $100 \%$ \\
\hline Total & $9 \%$ & $8 \%$ & $10 \%$ & $19 \%$ & $26 \%$ & $28 \%$ & $100 \%$ \\
\hline
\end{tabular}

$\mathrm{N}=748$ 


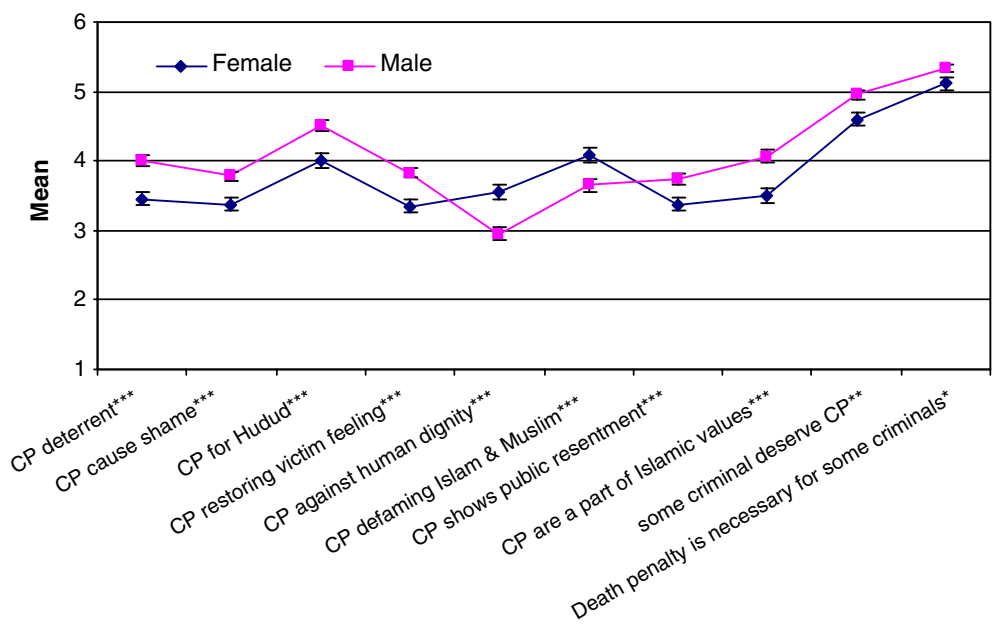

Fig. 3 Gender and Attitudes toward Corporal Punishment

significant supporters of the death penalty for some criminals ( $89 \%$ of both groups). These differences are statistically significant $\left(\chi^{2}=47,757 ; p=0,021\right)$.

Attitudes to Corporal Punishment

\section{Gender and Attitudes to Corporal Punishment}

The questionnaire surveyed the opinion of the respondents on different aspects of corporal punishment. The utility and effectiveness of these punishments as a penal instrument, the sacredness and divine character of them, the impact of their application on Islam and the face of Muslims in the world and their relationship with human dignity, were items on which the opinion of the respondents was asked. As indicated in Fig. 3, in all the items that refer to the effectiveness of corporal punishment and their necessity or viability for some criminals and crimes alike $(H u d u d)$, women score significantly lower than men. On the contrary, in the items pointing out the defamatory function of such punishments for Islam and Muslims and their contradiction with human dignity, woman significantly score higher than men. This finding supports the hypothesis that women are less punitive and supportive of corporal punishments than men. Though both men and women are undecided about the contradiction of corporal punishment with human dignity, women show more agreement with this contradiction than men.

\section{Profession and Attitudes to Corporal Punishment}

Figure 4 shows attitudes of different professional groups toward different aspects of corporal punishment. As shown in the figure there are some variances in the attitudes of respondents with different occupations. However, the most contrasting views are those of lawyers and police officers. Judges score relatively close to police officers.

Except for one item, corporal punishment is a part of Islamic values to which Tullab show more agreement than students; though these two groups hold relatively similar views to different items. This result refutes the survey hypothesis that Tullab are more punitive and supportive of the so called Islamic punishments than university students. 


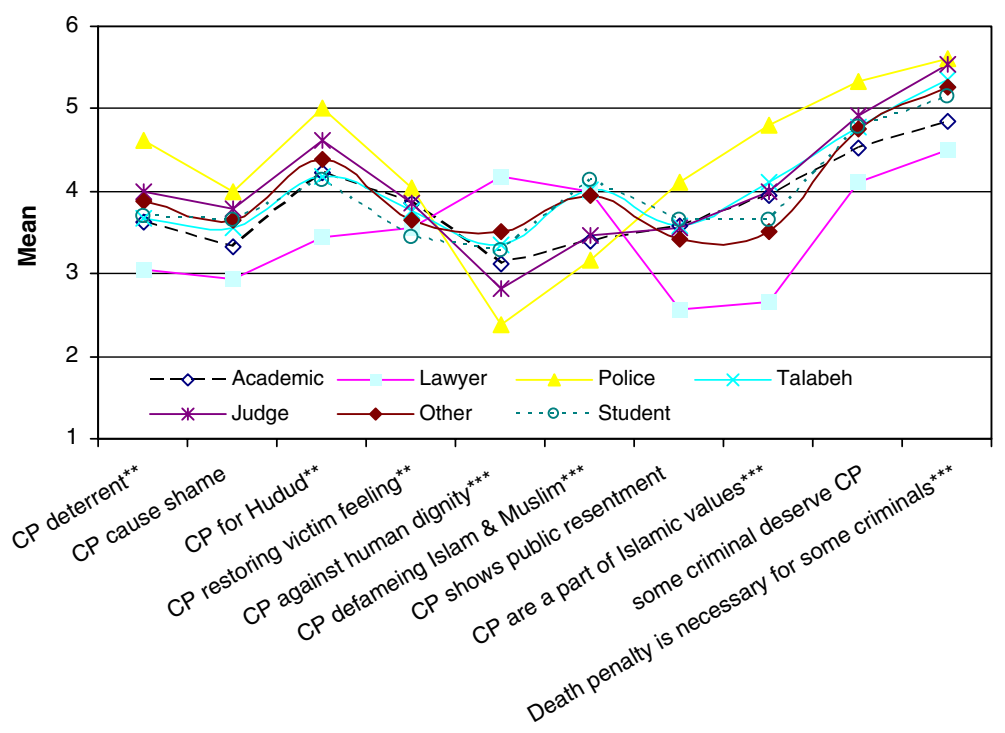

Fig. 4 Profession and Attitudes toward Corporal Punishment

\section{Criminal Law and Shari'a}

The discussion about the relationship between Shari'a and criminal law legislation dates back to the mid-nineteenth century when Muslims encountered the modern West and its civilization. Since then, different Islamic countries have tried, and are still trying, to respond to the challenges posed by Western civilization in various way. However, these discussions were set aside in favor of modernization and at the expense of the exclusion of Shari'a, when modernist monarchies took power. Since then, some Islamic societies have gone through legal reforms in the early twentieth century, Turkey under Atatürk, Iran under Reza Shah, Afghanistan under Amanullah Khan. Being aware of the economic, legal, cultural and political difficulties of their countries, in comparison with Western countries, they set out to modernize their nations through transplanting Western laws and institutions in their own countries. Nonetheless, Shari' $a$ and its bearers, though excluded and suppressed did not give up to competing with the Western secular form of social regulation. This resistance and competition is still at work in most of the Islamic countries, no matter if the state is a secular or Islamic one. In Iran, however, after the Islamic upheaval of 1979, secular modern laws were replaced by Shari'a, especially penal laws, or reconciled with it and reaffirmed by Islamic governors. However the tension between sacred law and secular law did not end up with the Islamic Revolution in 1979. The tension remained within Iran and, moreover, expanded to an international level. The Islamic state has been forced to protect and defend itself against critiques within and outside Iran and show that Shari' $a$ and the Islamic way of governance are effective and functional. The politics of Ijtihad is the only internal mechanism of evolution in Shari'a system and the Islamic state invokes it whenever expediency of the Islamic government requires change, invention or adaptation of a given legal element. As seen in Fig. 5, opinions of the respondents on different forms of relationship between Shari'a and the criminal law were asked. The respondents hold relatively homogenous views to different levels of the relationship between Shari' $a$ and criminal law; the selective suspension of some Islamic punishments, the adoption of more 
adaptive and modern reading of the Islamic penal rules, and the introduction of penal policies independent to and operating regardless of the Islamic penal laws and Shari'a. While most of the respondents disagreed or totally disagreed with the statement that there should be no direct relationship between Shari' $a$ and penal legislation $(60 \%)$, most of them agreed or totally agreed with the statement that the Shari'a should be interpreted and understood according to today's conditions of life (69\%). However, $20 \%$ are supportive of a distinction between Shari'a and penal legislation; $42 \%$ of the respondents endorsed the selective suspension of Islamic penal laws because of the international pressures on Iran, while $25 \%$ disagreed or totally disagreed with such a pragmatist view to Shari'a; $31 \%$ of the respondents supported the statement that current penal laws are suitable for securing social safety and $24 \%$ (totally) disagreed with it. Others agreed or disagreed to some extent with the proposition. There is no significant correlation between the gender of the respondents and their opinion on most of these statements. However the female and male respondents differ significantly in their view to the distinction between Shari'a and penal law legislation (chi square $=16,068 ; \mathrm{p}=, 007$ ). This difference may be explained by the fact that the Shari'a penal rules discriminate against women. The significant difference between male and female respondents is also observable in their opinion on the statement that "Islam has the best rules for combating crimes"; $22 \%$ of female respondents (totally) disagree with the statement, while $55 \%$ of them (totally) agree with it. For male respondents this proportion is respectively $11 \%$, against $71 \%(\mathrm{~N}=795)$. This difference is statistically significant (chi square $=28,853 ; \mathrm{p}=, 000)$.

However, as shown in Fig. 5 the respondents, both men and women, unanimously (totally) agree with the statement that the existing criminal laws should be reformed to be compatible with today's condition of society. Only $2 \%$ of female and $4 \%$ of male respondents (totally) disagree with this statement, while $86 \%$ of females and $85 \%$ of males (totally) agree with the statement.

As Fig. 6 indicates, respondents across different professions almost unanimously agree that the Shari'a criminal law should be interpreted according to today's conditions of life. The same homogeneity is observed in disagreement with this statement that there should be no relation between Shari'a and penal legislation. However, judges and Tulab show more disagreement than other professions. Lawyers tend to support this proposition more than others.

Most variance occurs in the views concerning the statement that the existing criminal law is suitable for securing safety. While most of the professions are undecided whether

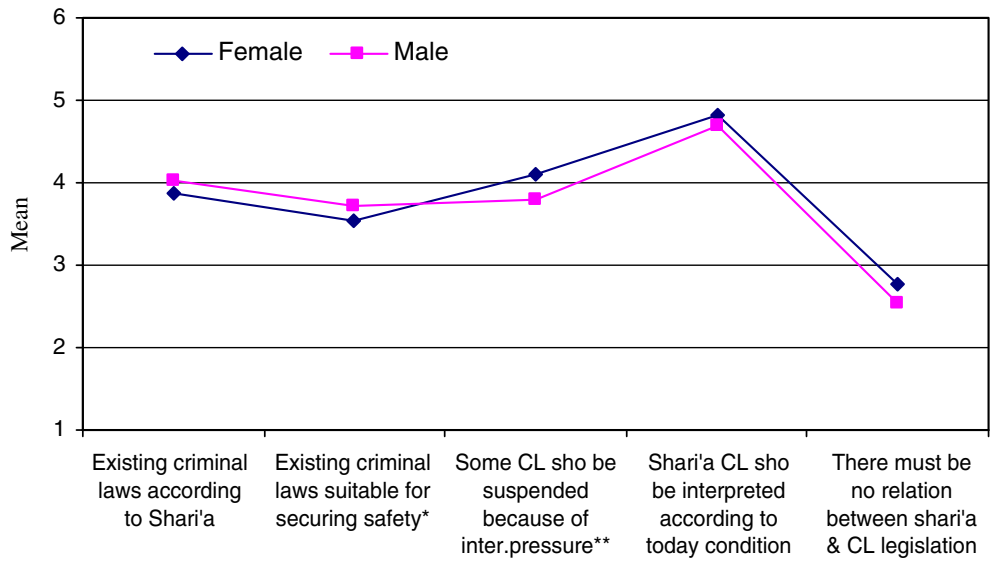

Fig. 5 Gender and Relationship between Penal Legislation and Shari'a 


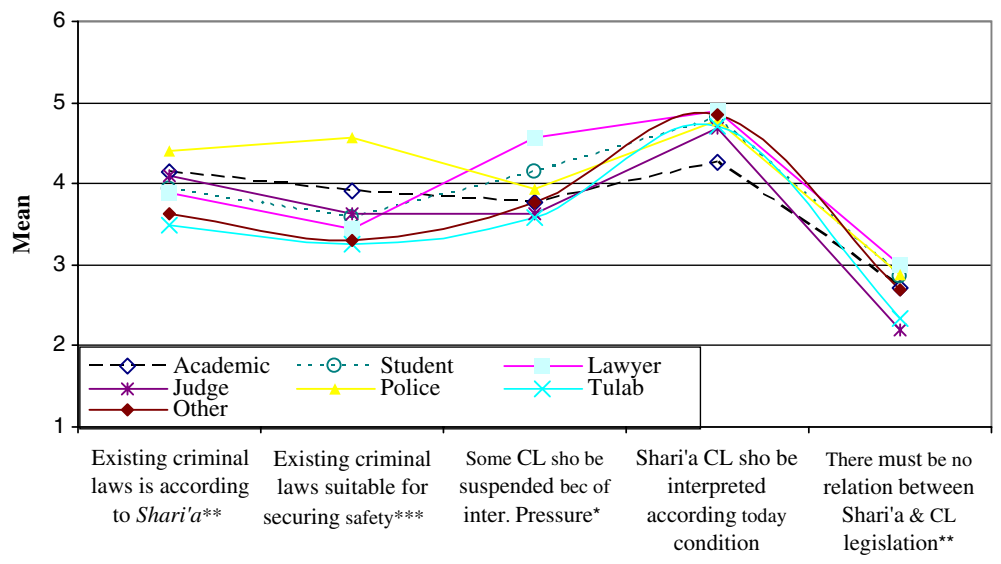

Fig. 6 Profession and Relationship between Penal Legislation and Shari'a

existing criminal laws are suitable for securing safety or not, police officers show agreement with this statement. Lawyers and students indicate more agreement with prudential suspension of some criminal laws because of international pressures. The least support for this proposition is given by judges and Tulab.

\section{Attitudes to Prison and Imprisonment}

Prison and imprisonment is one of the Taazir penal options that has been often criticized by different social groups, even by judicial and prison authorities, in recent years. Judicial authorities try to deflect the criticism from mismanagement and poor conditions of prisons to the undue and improper import of this institution from the West. Doing so, they question the very existence of this penal form as being inhumane, non-Islamic and alien to cultural tradition of Iran.

Moreover, by discrediting imprisonment, corporal punishments especially whipping, that is the second most used form of punishment, find more legitimacy. This form of punishment needs no special place and trained personnel. Therefore, it has no financial burden for the judiciary.

Shahroudi, the chief of the judiciary, in expressing his critique on being influenced by European countries in the overuse of prison as punishment, argues that in Islam imprisonment does not exist and is an exceptional penal measure. This is because imprisonment inflicts suffering mostly to the family of the offender and it is harmful to others [those who are innocent]. He then encourages judges to sentence the criminals to whipping rather than prison when both of these punishments are at their disposal. Nonetheless, he expresses his dissatisfaction with the judges sentencing behavior saying:

"Our judges, unfortunately, influenced by some malignant world publicity, do not accept whipping. In my view, whipping is one of the best, most just and fairest punishments. Because it's inflicted only to the offender and the offender's family are immune from side effects. This is especially so when it is accompanied by public shaming, because it is more of a deterrent" (ISNA 2008).

Nevertheless, the survey shows that most of the judges $(25 \%, \mathrm{~N}=176)$ (totally) disagree with the statement that "whipping is more humane than imprisonment". This is although $20 \%$ of them (totally) agree with the statement and the rest (37\%) hold an ambivalent opinion on this 
issue. However, among the whole respondents only a small number of them (totally) agree with this proposition and most of them (totally) disagree with it ( $22 \%$ versus $44 \%, \mathrm{~N}=793$ ).

As shown in Table 6, most of the judges agree that prisons are an academy of crime $(40 \%, \mathrm{~N}=177)$, while only $22 \%$ of them disagree with this proposition. However, in comparison with other groups, judges are less supportive of this statement. Tulab (students of religious seminary) hold the most skeptical view towards prison; $65 \%(\mathrm{~N}=71)$ of them (totally) agree with the statement that the prison is in fact an academy of crime. Nonetheless, it does not mean that, as the chief of the judiciary wishes, they support whipping instead of imprisonment. Most of them $(41 \%, \mathrm{~N}=73)$ oppose the statement that whipping is more humane than imprisonment. Only $23 \%$ of them (totally) agree with it.

Most of the respondents see prison as dysfunctional and rather as an academy for crime and a place where the offenders become more persistent and professional in criminal life. As indicated in Table 6, almost all different professional groups hold homogenous views toward prison. As the table shows, most of the respondents from different professional groups agree or to some extent agree that the prison is an academy of crime and that it makes criminals more professional. This is while most of them disagree with the statement that the prison is a place for rehabilitation of those who have a problematic social life $(49 \%)$, only $25 \%$ (totally) agree with this $(\mathrm{N}=799)$. Therefore, it is of no surprise to see that respondents overwhelmingly agree or totally agree with the statement that "our prisons should be reformed"; $92 \%$ of respondents $(\mathrm{N}=800)$. Apart from the widespread opinion that prisons are dysfunctional and counter-productive, most of the respondents agree or to some extent agree with the proposition that "prisoners are poor people while real criminals are living freely in society" (53\% totally agree or agree and $20 \%$ to some extent agree versus $17 \%$ disagreement, $\mathrm{N}=799$ ). This shows that prison's legitimacy is undermined not just because of poor conditions and mismanagement, but because prisons target those who have less social and political privileges. This stance toward prisons may mean that in the respondents' view these are poor people who mostly commit crime because of their poverty

Table 6 Multivariate regression analysis of independent variables' effect on some items

\begin{tabular}{|c|c|c|c|c|c|c|}
\hline & \multicolumn{2}{|c|}{$\begin{array}{l}\text { Death penalty is } \\
\text { necessary for some } \\
\text { criminals }\end{array}$} & \multicolumn{2}{|c|}{$\begin{array}{l}\text { There should be no direct } \\
\text { relationship between Shari'a and } \\
\text { penal legislation }\end{array}$} & \multicolumn{2}{|c|}{$\begin{array}{l}\text { A man who finds his adulterous } \\
\text { wife with other man may kill her } \\
\text { and the man }\end{array}$} \\
\hline & B & Beta & B & Beta & $\mathrm{b}$ & Beta \\
\hline (Constant) & 5,092 & & 2,986 & & 2,982 & \\
\hline Age $25-35$ & ,026 & ,009 &,- 389 &,$- 105 * *$ & ,200 &, 047 \\
\hline Age $36-45$ &,- 379 &,$- 088^{*}$ &,- 201 &,- 037 &, 082 &, 013 \\
\hline Age $>46$ &,- 117 &,- 019 &,- 163 &,- 022 &,- 048 &,- 006 \\
\hline Academic &,- 295 &,- 083 &, 003 &, 001 &,- 012 &,- 002 \\
\hline Lawyer &,- 623 &,- 066 & ,334 & ,028 &, 007 &, 001 \\
\hline Police &, 385 &, 057 &, 258 &, 030 & 1,143 &, $116^{* *}$ \\
\hline Other &, 115 &, 021 &,- 034 &,- 005 &,- 137 &,- 018 \\
\hline Judge &, 424 &, $125 * *$ &,- 478 &,$- 112 *$ &, 510 &, $103 *$ \\
\hline Missing & 177 &, 036 &,- 276 &,- 044 &,- 292 &,- 040 \\
\hline Talabe &, 480 & ,098* &,- 568 &,- 093 &, 029 &, 004 \\
\hline Men & ,158 &, 055 &,- 050 &,- 014 & 1,020 &, $246 * * *$ \\
\hline $\mathrm{R}^{2}$ & 0,038 & & 0,032 & & 0,121 & \\
\hline
\end{tabular}

Note: Students who are younger than 25 years old are reference group

$\mathrm{p}<.05, * * \mathrm{p}<.01, * * * \mathrm{p} .001$. 
and enter the penal process which ends up with prison because they are not able to pay a fine. Once entered into prison they have little means, whether legal, social or political, for release on parole or as clemency or to benefit from other release opportunities which are granted by the prison authorities.

\section{Effect of Independent Variables on Respondents' Attitudes}

The weight of the effect of each independent variable on variations of attitudes was examined through multivariate regression. The multivariate regression analysis shows that the effect of independent variables (age, profession, and gender) on respondents' attitudes is very small. It seems that the variations may not be interpreted through these variables.

For instance, as shown in Fig. 3, although the degree of the support of death penalty and gender of the respondents are significantly correlated, the effect of gender on this variable is very small $\left(\mathrm{R}^{2}=.006\right)$. The profession of the respondents has a greater effect, though still small, on the degree of support of death penalty $\left(\mathrm{R}^{2}=.028\right)$. The same is true for attitudes toward this item that there should be no direct relationship between Shari'a and penal legislation. In spite of the significant association between gender of the respondent and their support of the distinction between Shari'a and penal legislation, the impact of gender on this variable is very small $\left(\mathrm{R}^{2}=.005\right)$. The profession again has more impact $\left(\mathrm{R}^{2}=.025\right)$. The impact of gender on respondents' attitudes to impunity of honor killing is, expectedly, more than the effect of the profession (respectively; $\mathrm{R}^{2}=.093, \mathrm{R}^{2}=.59$ ).

\section{Discussion}

This study shows that most of the respondents hold relatively similar views to the surveyed items in spite of the age and professional differences. This may be the result of sacred representation of penal policies and options in Iran. As discussed above, the majority of the respondents, in spite of the significant difference between men and women, believe that Islam has the best rules for combating crimes. In the respondents' view Islam is something more than a religion which is to regulate the spiritual relationship between individuals and God. Islam, as a formal ideology of the state in Iran, is utilized as the legitimate base of public policy making.

As was expected, women are less supportive of corporal punishments than men; as shown above this difference is statistically significant. However, as regards the death penalty women, though supporting the death penalty less than men, differ very little in their view to this penal form and the difference is not significant. They support Shari'a penal options less than men though this is again statistically not significant. The most striking and statistically significant difference between male and female respondents is observed in their view to the impunity of honor killing, which currently is laid down in Article 630 of Islamic Penal Code of Iran (p. 20 footnote).

Among professional groups the most striking difference is observed between police officers and judges on one side, and other professions on the other side, in that police officers and judges support the Shari'a penal options significantly more so than other groups. The survey results refute the assumption that Tulab support the Shari'a penal measures more than other groups. As indicated above they hold a very similar view to university students in different issues. However, like judges, they disagree more strongly than other groups with the statement that there should be no direct relationship between Shari'a and penal legislation. They also are less supportive of the selective suspension of 
Islamic penal laws because of international pressure. On the other hand, like most of the professional groups, they (totally) agree with the statement that the Shari'a criminal laws should be interpreted according to today's conditions of life.

As hypothesized prisons enjoy very little legitimacy in Iran. As shown in Table 6, most of the respondents (totally) agree with the statement that the prison is in fact an academy of crime. The legitimacy crisis of prisons could make the application of whipping as an alternative punishment more legitimate; this is because at the moment whipping is the only effective alternative punishment which is accessible to judges. Refuting this assumption, the survey shows that most of the respondents oppose the statement that whipping is more humane than imprisonment. $41 \%$ of academics (versus 20\%), 64\% of lawyers (versus $12 \%$ ), $25 \%$ of police officers (versus $33 \%$ ), $41 \%$ of Tulab (versus $23 \%$ ), $43 \%$ of "other" professions (versus 27\%), $45 \%$ of students (versus $22 \%$ ) and finally $41 \%$ of academics (versus 29\%), (totally) disagree with this abatement $(\mathrm{N}=724)$. Most of the respondents believe that some of the offenders should be sentenced to community services instead of imprisonment $(83 \%$ of respondents versus $6 \%)$.

\section{Concluding Remarks}

Being committed to applying Islamic Shari'a with a literal interpretive approach to Islam, as well as at the same time striving to bring justice, peace and security in an ever-changing social context, places Islamic rulers under a great dilemma. The only solution to this situation may be the adoption of a moderate and more compatible view to Islam through a dynamic and diachronic Ijtihad. Many Islamic intellectuals have called for such an evolution in Figh (Islamic laws) and its methodology (Usul al Fiqh).

However, notwithstanding the frequent and widespread call for the revision of Islamic jurisprudence throughout the Islamic world and in spite of the theoretical possibility for change and evolution, Islamic Shari'a has remained unresponsive to some public demands.

Despite this, the penal Shari'a (law) makers, while being unwilling or unable to undertake a through and comprehensive strategy of change, try to take an active role in responding to their environment. This is true for both the national and international environment.

For instance, in response to the frequent human rights violation warnings issued by Western countries or international human rights organizations against Iran, the secretary of the Human Rights Commission of the judiciary, in an interview, argues: "The West tends to impose its own interpretation from the human rights documents to us whereas we have our own interpretation of them." Alternatively, he finds the related initiative of member states of the non-allied movement in their recent meeting in Tehran very promising. In this meeting these states decided to interpret the human rights documents according to the local and cultural values.

Pointing to the administration of the punishment of stoning in Iran, which has aroused much both inside and outside Iran, he argues that "most Western critiques of us have a political incentive and they want to put us under pressure." In conclusion, he reminds us that Shari'a, whether Shiite or Sunnite, is not the Shari'a of the shame, because it is based on the Quran, the consensus of Islamic jurists and reason (Aql). However he insists that the system [Islamic Republic] is very sensitive with regarding such cases and rightly advises judges to be more careful in delivering such sentences [like stoning] (ISNA 2007).

It is true that through punishment, sovereignty comes to be represented (Macbride 2007). The Shari'a punishments have been imbedded deeply in Islamic sovereignty (political and 
cultural order). Therefore, as discussed above, during the last four years under the new politics of the Islamic state and the rhetoric of the return to the virtues of the Islamic Revolution, criminal punishment, in response to the emerging demand for reform and change, has turned out to be inflicted in a fast, visible (public) and massive way.

Acknowledgement I am highly indebted to Prof. H. J. Albrecht, Director of the Max Planck Institute for Foreign and International Criminal Law, who suggested and supported the development of my empirical research. I would also like to thank Volker Grundies, Harald Arnold, Dietrich Oberwittler, Helmut Kury, and Michael Wuerger, without whose help I would not have been able to undertake this empirical research. I am also grateful to Iranian colleagues, professors and respondents who helped me in administering the questionnaire.

\section{References}

Albrecht, H. J. (2002). Post-adjudication dispositions in comparative perspective. In M. Tonry, \& R. S. Frase (Eds.), Sentencing and sanctions in western countries (pp. 293-330). Oxford: Associate Press, Thursday, 23 March 2000.

Bottoms, A. (1995). The philosophy and politics of punishment and sentencing. In C. Clarkson, \& R. Morgan (Eds.), The politics of sentencing reform (pp. 16-49). Oxford: Clarendon Press.

Brown, N. J. (1997). The rule of law in the Arab world. Cambridge University Press.

Garland, D. (1990). Framework of inquiry in the sociology of punishment. The British Journal of Sociology, $41(1), 1-15$.

Garland, D. (2001). The culture of control crime and social control in contemporary society. Oxford University Press.

Geertz, C. (1983). Local knowledge. Basic Books, 2000.

Grafinkel, H. (1956). Conditions of successful degradation ceremonies. The American Journal of Sociology, 61(5), 420-424.

Human Development Report 2007/2008, UNDP.

ILNA, (Iranian Labor News Agency), Interview with the chief of the prison organization, 23 Feb 2006.

ISNA, Iranian Students News Agency, 01-06-2008 (1386/10/16) Code of News: 8610-08186.

ISNA, Iranian Students News Agency, 10-26-2007 (1386/08/04) Code of News: 8608-01492 and in 08-012007 (1386/05/10), Code of News: 8605-05686, Interview with the General Prosecutor of Mashad and Zahidan.

ISNA, Iranian Students News Agency, Interview with the Chief Justice of Provincial Appeal Court of Tehran (2007).

ISNA News Agency, interview with Yassaqi, president of prisons organization, Legal News Division, 1385/ 07/14 (10-06-2006) code of news: 8507-05131.

ISNA, Iranian Students News Agency, TV interview of the head of the judiciary, 06-25-2008 (1387/04/05), code of news: 8704-02755

ISNA, Iranian Student News Agency, 09-30-2007 (1386/07/08), Code of news: 8607-01349

Kury, H., et al. (2002). Strafeinstellungen, eine vergleich zwischen Ost und West Deutschland, Max Planck Institut für ausländisches und internationales Strafrecht, Freiburg.

Macbride, K. (2007). Punishment and political oder. The University of Michigan Press.

Miri Ashtiyani, E. (1385), (2006), Jameeh Shenasi Etiyad Dar Iran Emrouz, (Sociology of Addiction in Today Iran), Muhajer Publication.

Nietzsche, F. (1967) On the Genealogy of Morals and Ecce Homo, translated by Kaufmann, W., Random House, Inc.

Quran, Sura Al-Baqara, Chapter 2, Verse 179 and 178.

Reuters, Mon 5 Nov 2007.

SPA (Saudi Arabia News Agency), 12th March 2003.

South Africa Press Association, 21/07/2006.

Usmani, M.T. (2006). The Islamization of Laws in Pakistan: the case of Hudud ordinances, The Muslim World, Vol. 96. 